\title{
PReS-FINAL-2176: Declines in levels of disease activity and physical disability in children with juvenile idiopathic arthritis seen in standard clinical care over the last 25 years
}

\author{
A Consolaro ${ }^{1 *}$, S Lanni ${ }^{1}$, F Minoia', S Davì ${ }^{1}$ S Dalprà ${ }^{1}$, B Schiappapietra ${ }^{1}$, V Muratore ${ }^{2}$, A Martini ${ }^{1,3}$, A Ravelli ${ }^{1,3}$
}

From 20th Pediatric Rheumatology European Society (PReS) Congress

Ljubljana, Slovenia. 25-29 September 2013

\section{Introduction}

Over the last 3 decades there have been important advances in the management of juvenile idiopathic arthritis (JIA), which include the introduction of methotrexate and, later on, the tendency toward its earlier initiation, the widespread use of intra-articular corticosteroid injections, and, more recently, the availability of the biologic response modifiers. Although this therapeutic progress is likely to have led to a marked improvement in the outlook of children with JIA, the prognostic impact of the newer therapeutic modalities is still poorly documented.

\section{Objectives}

To evaluate the change in the measures of disease activty and phisical function in JIA over the last 25 years.

\section{Methods}

The clinical information recorded during visits made in children with JIA from January 1987 to March 2012 was retrieved from the study center database. Visits were divided in the following time intervals: 1987-1995 $(\mathrm{n}=826), 1996-2000(\mathrm{n}=1,337), 2001-2005(\mathrm{n}=$ 2,022), 2006-2012 ( $\mathrm{n}=2,317)$. Measures of disease activity included the physician's and parent's global ratings (both made on a $0-10 \mathrm{~cm}$ visual analog scale, VAS), the parent's pain rating (made on a $0-10 \mathrm{~cm}$ VAS) and the count of joints with swelling, pain on motion/tenderness and active disease. Measures of disability included the count of joints with restricted motion and a physical function tool (the Childhood Health Assessment Questionnaire, CHAQ before March 2007 and the Juvenile Arthritis Functionality Scale, JAFS after that date). To enable comparability of functional ability evaluations, both CHAQ and JAFS scores were converted to a $0-10$ scale $(0=$ best; $10=$ worst). Parent's global and pain ratings as well as functional ability assessment were not available for visits made prior to 1995 because before this year these assessments were made on a scale not comparable with those used subsequently.

\section{Results}

We observed a progressive decline in the levels of disease activity and physical disability over time among children with JIA seen from the mid of the 1980s to the 2010s. This finding confirms the notion that the recent advances in the management of JIA have led to a substantial improvement in disease prognosis.

\section{Conclusion}

We observed a progressive decline in the levels of disease activity and physical disability over time among children with JIA seen from the mid of the 1980s to the 2010s. This finding confirms the notion that the recent advances in the management of JIA have led to a substantial improvement in disease prognosis.

\section{Disclosure of interest}

None declared.

${ }^{1}$ Pediatria II, Istituto Giannina Gaslini, Genoa, Italy

Full list of author information is available at the end of the article 
Table 1

\begin{tabular}{lccccccccc}
\hline & $\begin{array}{c}\text { Physician global } \\
\mathbf{( 0 - 1 0 )}\end{array}$ & $\begin{array}{c}\text { Active } \\
\text { joints }\end{array}$ & $\begin{array}{c}\text { Swollen } \\
\text { jointst }\end{array}$ & $\begin{array}{c}\text { Tender } \\
\text { joints }\end{array}$ & $\begin{array}{c}\text { Restricted } \\
\text { joints }\end{array}$ & $\begin{array}{c}\text { Parent global } \\
(\mathbf{0}-\mathbf{1 0})\end{array}$ & $\begin{array}{c}\text { Parent pain } \\
(\mathbf{0}-10)\end{array}$ & $\begin{array}{c}\text { Physical function } \\
(\mathbf{0}-10)\end{array}$ \\
\hline $1988-1996$ & $5.4(2.8)$ & $8.2(9.4)$ & $7.9(8.3)$ & $6.3(8.0)$ & $8.0(10.4)$ & - & - & - \\
$1996-2000$ & $5.0(3.4)$ & $5.7(8.4)$ & $4.3(5.8)$ & $4.3(7.9)$ & $5.5(9.5)$ & $2.8(2.5)$ & $2.5(2.5)$ & $1.7(2.0)$ \\
$2001-2005$ & $4.0(3.5)$ & $3.8(5.7)$ & $2.9(4.2)$ & $3.3(6.0)$ & $3.1(6.2)$ & $2.4(2.5)$ & $2.4(2.7)$ & $1.3(1.8)$ \\
$2006-2012$ & $2(2.7)$ & $2.2(4.5)$ & $1.8(3.8)$ & $1.9(4)$ & $1.9(4.2)$ & $2.1(2.5)$ & $1.9(2.6)$ & $0.4(0.9)$ \\
\hline
\end{tabular}

\section{Authors' details}

'Pediatria II, Istituto Giannina Gaslini, Genoa, Italy. ${ }^{2}$ Pediatria, IRCCS

Fondazione Policlinico San Matteo, Pavia, Italy. ${ }^{3}$ University of Genoa, Genoa,

Italy.

Published: 5 December 2013

doi:10.1186/1546-0096-11-S2-011

Cite this article as: Consolaro et al:: PReS-FINAL-2176: Declines in levels of disease activity and physical disability in children with juvenile

idiopathic arthritis seen in standard clinical care over the last 25 years. Pediatric Rheumatology 2013 11(Suppl 2):O11.

Submit your next manuscript to BioMed Central and take full advantage of:

- Convenient online submission

- Thorough peer review

- No space constraints or color figure charges

- Immediate publication on acceptance

- Inclusion in PubMed, CAS, Scopus and Google Scholar

- Research which is freely available for redistribution

Submit your manuscript at www.biomedcentral.com/submit 